\title{
Malaysia Moving Towards a Sustainability Municipal Waste Management
}

\author{
Yien Yu Tang ${ }^{*}$, Kuok Ho Daniel Tang ${ }^{2}$, Amit Kumar Maharjan ${ }^{3}$, Azrina Abdul Aziz ${ }^{4}$, \\ Seng Bunrith ${ }^{5}$ \\ ${ }^{1}$ Department of Civil Construction Engineering, Faculty of Engineering Science, Curtin University, CDT 250, Miri, 98009 , \\ Sarawak, Malaysia \\ ${ }^{2}$ Environmental Science Program, Division of Science and Technology, BNU-HKBU United International College, 2000 \\ Jintong Road, Tangjiawan, Zhuhai GD 519087, China \\ ${ }^{3}$ Interdisciplinary Centre for River Basin Environment, University of Yamanashi, Japan. \\ ${ }^{4}$ Faculty of Civil Engineering Technology, Universiti Malaysia Pahang, Lebuhraya Tun Razak, 26300 Gambang, Kuantan \\ Pahang Darul Makmur, Malaysia \\ ${ }^{5}$ Faculty of Hydrology and Water Resource Engineering, Institute of Technology Cambodia, PO BOX 86, Russian Federation \\ Bvld, Phnom Penh, Cambodia \\ *Correspondence: yienyutang@gmail.com
}

SUBMITTED: 27 November 2021; REVISED: 18 December 2021; ACCEPTED: 20 December 2021

\begin{abstract}
The elevation of waste generation subsequent to population growth has become a severe environmental topic in Malaysia. Since most of the waste is being dumped into a landfill, the open dumpsite, or unsanitary landfills which are not constructed with proper engineering plan, severe impacts on the environment result. The energy demand in Malaysia increased with the growing population, but reliance on fossil fuels to generate electricity has created another greenhouse gas contributor. Alternatively, waste-to-energy technology solves the problem of increasing waste by converting the waste to a renewable energy source. Malaysia has moved towards landfill gas recovery system and incineration for waste energy recovery. The recovery system and refuse-derived fuel plant achieved expectation; however, the incineration plants have failed due to the opposition of the public, lack of funding and technician expertise, and other technical issues. The solid waste management practices lacking separation and recycling sources, become an obstacle for development. The government puts effort into solving the current issue by promoting recycling in the public, enforcing the legislation, and approaching new technologies for better solid waste management practice in the future. This paper aims to discuss the application of energy recovery from municipal solid waste in Malaysia.
\end{abstract}

KEYWORDS: Municipal solid waste; waste-to-energy technologies; landfill; incineration; sustainability

\section{Introduction}

Malaysia is a developing country that experiences rapid urbanization and population growth. Consequently, the generation of municipal solid waste (MSW) is increasing as it has a 
proportional relationship with the population growth rate, and it is predicted to reach 49670 tons per day by 2030 [1]. MSW encompasses the waste produced from residential, commercial, institutions and parks [2]. Currently, the average MSW generated in Malaysia is 0.5-0.8 $\mathrm{kg} /$ person/day, but it may differ depending on the development status of the states in the nation [3]. However, Malaysia has improper waste management due to the lack and limitation of technology, lack of skilled manpower, and the facilities that can effectively solve the issue in the country. Besides, the lifestyles of the public over the past few decades have resulted in a complicated composition of MSW. As the public lack of proper knowledge and have a poor attitude and participation in waste recycling, only $1 \%$ of organic and $5.5 \%$ of recyclable products out of $45 \%$ and $35 \%$ of the waste stream were utilized in 2006. Most of the MSW ends up being disposed in the unsanitary landfills and open dumpsites without further treatment. Therefore, it creates a serious environmental issue including soil and groundwater contamination through migration of leachate, emission of greenhouse gas (GHG) that leads to global warming and climate change, air pollution as well as fires and explosion incidents [4]. On the other hand, the energy demand is also growing rapidly in response to population growth. It is predicted to increase approximately $4.7 \%$ annually where the annual growth rate of electricity consumption is $8.1 \%$ [3]. Malaysia mainly relies on burning fossil fuels and natural gas to generate electricity. However, fossil fuel-based energy sources will generate carbon dioxide $\left(\mathrm{CO}_{2}\right)$ which is one of the major GHG that contributes to global warming. It is

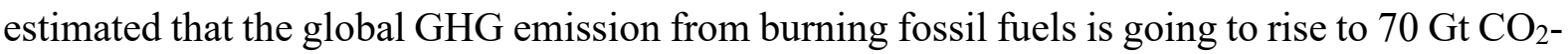
eq in 2050 [5]. In order to combat this issue, most of the countries approach renewable energy as a replacement for fossil fuel to fulfil the energy demand. In Malaysia, the energy sector and waste sector contribute to $80 \%$ and $9 \%$ of the GHG emission respectively [6].

Taking the two problems into consideration, energy recovery through waste-to-energy (WtE) technology would be the best solution to tackle the issues simultaneously as it can promote sustainable MSW management. The concept of WtE is to reduce the organic fraction of MSW and generate a valuable amount of heat and energy from non-recyclable MSW. MSW in this case can be considered as a renewable source for energy recovery. Thus, the MSW that entered the landfill is decreased, the use of fossil fuel and other non-renewable energy are reduced, and eventually the emitted GHG is minimized. WtE technologies can be classified into biological technology (e.g., anaerobic digestion and microbial fuel cell), thermal technology (e.g., incineration, pyrolysis, and gasification) and landfilling with gas recovery. Table 1 shows the different types of $\mathrm{WtE}$ technologies with their pros and cons while Figure 1 presents $\mathrm{WtE}$ technologies with the products. Malaysian government has also decided to adopt these sustainable promising solutions and discard the previous practice which used mostly unsanitary landfill and open dumpsite that result in severe environmental issue. WtE technologies implemented in Malaysia at present is landfilling with gas recovery and incineration [1]. The objective of this paper was to discuss the application of energy recovery from municipal solid waste in Malaysia. This paper covers the policies related to MSW and renewable energy (RE), the solid waste management practice, and introduction to WtE technologies implemented in Malaysia. Besides, an overview of major challenges, future challenges and prospects are summarized in order to identify the current issue and measurements are provided to improve the situation. 
Table 1. Different types of WtE technologies

\begin{tabular}{|c|c|c|c|c|c|}
\hline Type & $\begin{array}{c}\text { WtE } \\
\text { Technologies }\end{array}$ & Mechanism & Advantages & Disadvantages & Reference \\
\hline \multirow[t]{4}{*}{$\begin{array}{l}\text { Thermal } \\
\text { Treatment }\end{array}$} & Incineration & $\begin{array}{l}\text { Burning the whole mass of waste } \\
\text { in incinerator with excess air } \\
\text { under high pressure. }\end{array}$ & $\begin{array}{l}\text { - Reduce waste } \\
\text { - On site incineration } \\
\text { - Minimize air emission } \\
\text { - Aseptic ash is obtained } \\
\text { - Less space requirement }\end{array}$ & $\begin{array}{l}\text { - High capital cost } \\
\text { - Skilled labour is required } \\
\text { - High moisture content affects the combustibility } \\
\text { - Environment issues if flue gas is not handled properly } \\
\text { - Health risk }\end{array}$ & [7] \\
\hline & Gasification & $\begin{array}{l}\text { Carbonaceous and organic waste } \\
\text { materials are converted into } \\
\text { synthetic gas called syngas } \\
\text { through indirect combustion in } \\
\text { the presence of gasifying agent } \\
\text { such as air or steam }\end{array}$ & $\begin{array}{l}\text { - More effective than incineration } \\
\text { - Can treat high quality of inorganic waste } \\
\text { - Produce multiple secondary clear fuel } \\
\text { - Minimum emission }\end{array}$ & $\begin{array}{l}\text { - High capital cost } \\
\text { - Skilled labour is required } \\
\text { - The efficiency can be affected by high moisture content } \\
\text { - High energy consumption if moisture content is high } \\
\text { - The quality of fuel is affected by the properties of waste }\end{array}$ & {$[7,8]$} \\
\hline & $\begin{array}{l}\text { Plasma } \\
\text { Gasification }\end{array}$ & $\begin{array}{l}\text { Convert waste and hazardous } \\
\text { materials into their respective } \\
\text { constituent elements. }\end{array}$ & $\begin{array}{l}\text { - High efficiency } \\
\text { - High flexibility } \\
\text { - Take place incompletely closed system } \\
\text { - Regained metals are returned to } \\
\text { metallurgic industries } \\
\text { - Obtained slag can be used in road and } \\
\text { cement industry } \\
\text { - Can treat electronic waste }\end{array}$ & $\begin{array}{l}\text { - High capital cost } \\
\text { - High specific energy consumption } \\
\text { - Low service life } \\
\text { - High exergy destruction ratio }\end{array}$ & {$[7,9,10]$} \\
\hline & Pyrolysis & $\begin{array}{l}\text { An endothermic process takes } \\
\text { place in oxygen free environment } \\
\text { and vaporous parts of feedstock } \\
\text { are vaporized on heating. }\end{array}$ & $\begin{array}{l}\text { - High recovery rate } \\
\text { - Less space requirement } \\
\text { - Lower temperature requirement } \\
\text { - Wider feedstock range } \\
\text { - Can be categorized into slow, fast and flash } \\
\text { pyrolysis depending on the required } \\
\text { conditions }\end{array}$ & $\begin{array}{l}\text { - High capital cost } \\
\text { - Skilled labour is required } \\
\text { - The process is influenced by various factors. } \\
\text { - Fume incineration is necessary to destroy hazardous } \\
\text { organic compounds. } \\
\text { - The efficiency can be affected by high moisture content }\end{array}$ & {$[11,12]$} \\
\hline \multirow[t]{2}{*}{$\begin{array}{l}\text { Biological } \\
\text { Treatment }\end{array}$} & $\begin{array}{l}\text { Anaerobic } \\
\text { Digestion }\end{array}$ & $\begin{array}{l}\text { Natural biodegradable process of } \\
\text { organic compounds by } \\
\text { microorganisms in the absence of } \\
\text { air }\end{array}$ & $\begin{array}{l}\text { - Suitable for organic waste treatment } \\
\text { - Adapted to a broader range of organic } \\
\text { substrate } \\
\text { - Low environmental impact } \\
\text { - High energy recovery potential }\end{array}$ & $\begin{array}{l}\text { - Long duration of microbial reaction } \\
\text { - High nitrogen rich components and cations in waste } \\
\text { stream increase ammonia and salt concentration that } \\
\text { makes the process toxic for methanogenic activities } \\
\text { - Require sufficient waste for operation } \\
\text { - Produce intermediate compound }\end{array}$ & {$[7,13,14]$} \\
\hline & $\begin{array}{l}\text { Aerobic } \\
\text { Composting }\end{array}$ & $\begin{array}{l}\text { Organic matter is exposed to } \\
\text { microbial decomposition in } \\
\text { humid, hot, aerobic, and }\end{array}$ & $\begin{array}{l}\text { - Suitable for organic waste treatment } \\
\text { - Acts as soil conditioner } \\
\text { - Improve soil quality } \\
\text { - Acts as organic input in agriculture }\end{array}$ & $\begin{array}{l}\text { - Long duration of microbial reaction } \\
\text { - Larger area requirement } \\
\text { - High transportation cost } \\
\text { - Lower nutrient value }\end{array}$ & {$[11]$} \\
\hline
\end{tabular}


anaerobic environments under a controlled condition

Physical Refused-

Treatment

Refused-

The non-recyclable solid waste is burnt as fuel/feedstock

to produce electricity.

- Simple

- Higher efficiency

- Lower excess air requirement

- High calorific value

- Fewer byproducts

- Less environmental impact

Landfill Gas The landfill gas generated by the Recovery decomposition of organic matter

in the landfill is captured and converted to electricity.
- Reduce greenhouse gas emission

- Landfill gas can be utilized as fuel

- Electricity can be generated
- Chances of infection agents

- Bad smells

- High pre-processing cost

- High maintenance cost

Higher chances of explosion during the shredding

process

Produce flue gases and activated sludge that contain high concentration of heavy metals

- May cause unpleasant smell

Have fire and explosion risk

The production of landfill gas is affected by various factors

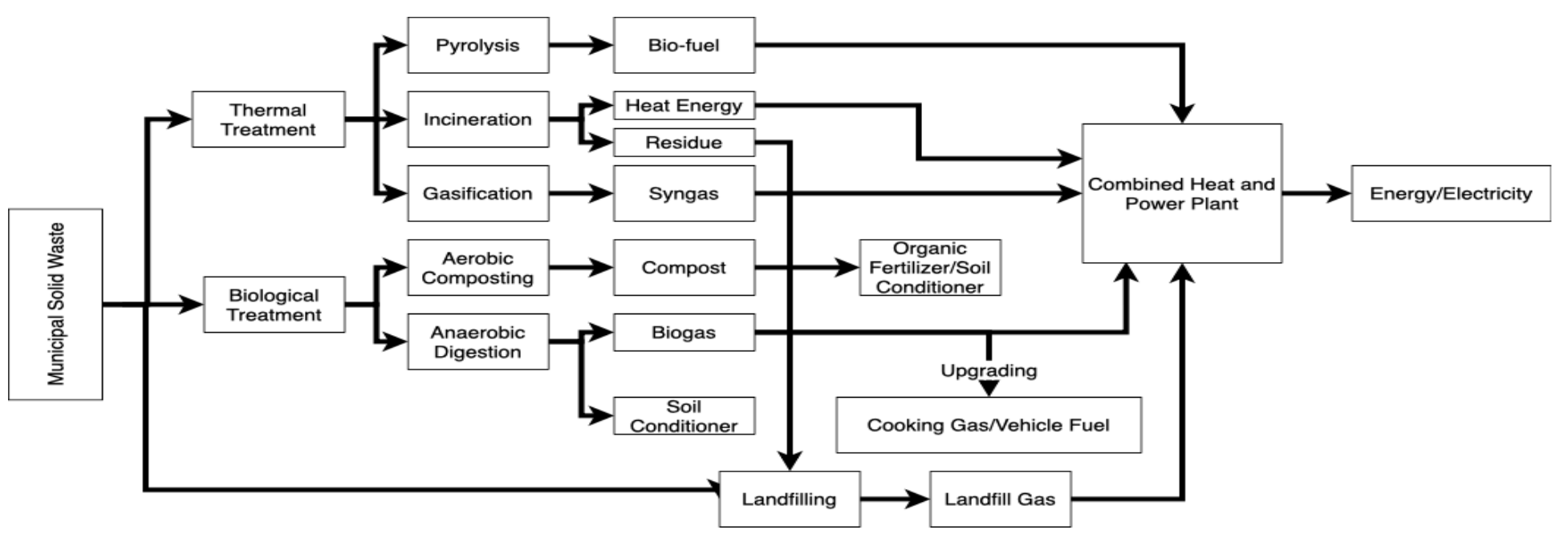

Figure 1. WtE technologies and the product 


\section{Overview of major challenges}

The development of WtE technologies, particularly incineration, is facing challenges from political, economic and technological factors. The suggestion of constructing a large-scale and centralized incineration system has been protested by the public due to health hazards associated with the emission of dioxins and other toxic compounds. Besides, there are difficulties in the disposal of inorganic residue and monitoring facilities due to technical limitations. The problem of meeting the stringent emission standard of incineration also remains as it is much lower compared to other combustion plants. Insufficient funding in $\mathrm{WtE}$ technologies has also been one of the obstacles of WtE development [16]. Source separation and recycling practices can save the manufacturing cost for MSW segregation and generate maximum energy from MSW simultaneously [1]. The lack of waste sorting and separation practice can corrode the equipment of the incinerator due to the high concentration of chlorine and sulphur in the MSW that might form acid gases during combustion [17]. With the increasing population growth and upgrading lifestyle, the public has led to an overconsuming trend with an outcome of many unnecessary wastes being generated. However, source separation and recycling practices are still at the infant age as the public lack understanding, awareness and correct perception of recycling. They cannot turn the knowledge into behavior as well as connect the benefits of the practice and the consequence of not practicing, thus leading to a low recycling rate in Malaysia. They tend to put all the responsibility on the local authorities and municipal waste collectors to deal with the waste problems. On the other hand, the effective solutions are inflexible due to lack of knowledge and technical expertise. The Federal and State legislation does not fully undertake the responsibility of solid waste management, resulting in a poor linkage and cooperation among each of the stakeholders. Consequently, the recyclables collection efficiency is reduced. In addition, detailed and accurate data regarding waste generation and composition as well as the number of operating waste management within municipalities is presently absent, impeding proper planning for future policies in implementing waste minimization among households $[18,19]$.

\section{Policies of municipal solid waste management and renewable energy in Malaysia}

MSW is a type of solid waste under the responsibility of the Ministry of Housing and Local Government (MHLG). The implementation of the Action Plan for a Beautiful and Clean Malaysia (ABC Plan) in 1987 had given an idea to the Malaysian on MSW management and its importance on maintaining public health and environmental sustainability by reducing the generation of solid wastes. However, the plan had failed to be authorized as there was lack of legal and fiscal instruments for management. In 1995, the concept of federalization and privatization was introduced to overcome the various problems, including lack of financial and funding, lack of expertise, unequaled quality service and illegal dumping as well as open burning. Again, the concept didn't work well due to the lag of payment for private concessionaires, leading to the inefficiency of waste collection services. National Strategic Plan (NSP) was adopted in 2005 to provide a judicious solid waste management framework in Malaysia in line with Vision 2020. NSP highlighted to upgrading the non-sanitary landfill and constructing new sanitary landfills [3]. In response to NSP, the first sanitary landfill was implemented, the concept of energy recovery through WtE technologies was developed and source separation, waste reduction, reuse, and recycling were encouraged. Solid Waste and 
Public Cleansing Management Act 2007 (Act 672) is formulated in 2007 to promote waste reduction and recycling and to ban illegal dumping. National Solid Waste Management Department (Jabatan Pengurusan Sisa Pepejal Negara - JPSPN) and Solid Waste and Public Cleansing Management Corporation (SWCorp Malaysia) are the two agencies established under the Solid Waste Management and Public Cleansing Corporation Act 2007 (Act 673) to make sure that Act 672 is carried out properly. JPSPN is responsible for proposing, formulating and setting different plans policies and standards while SWCorp Malaysia is responsible for implementation, enforcement and recommendation. SWCorp Malaysia also implements the SWCorp Strategic Plan 2014-2020 which emphasize seven core strategies to be used as a major reference of solid waste management up until 2020 [19].

Regarding RE, Five Fuel Diversification Policy was the first policy that included RE as an energy source and aimed to contribute $5 \%$ of RE in the total energy mix by 2005 in the 8th Malaysia Plan. In the 9th Malaysia Plan, Small Renewable Energy Power Program, BioGen project and Malaysia Building Integrated Photovoltaic Technology Application Project (MIPV) were introduced, and incentives were given to companies that utilized RE technologies to further supply RE in the total energy mix. National Green Technology enforced in 2009 emphasized the application of green technology in enhancing sustainable development in order to achieve a national energy mix with $5.5 \%$ of RE. Under this policy, Green Technology Financing Scheme (GTFS) is available to provide fund to the company that employs green technology for energy, water and waste management for 15 years. Under thrust 1 of the Renewable Energy Policy and Action Plan 2010, which is introduced as an appropriate legal framework, the Feed-in Tariff (FiT) is implemented for RE producers. The FiT programme enables the RE producers to sell the electricity that used RE resources to the national grid at a fixed premium price for a specific length of time. In the 11th Malaysia Plan, the idea of sustainable consumption and production is adopted, and landfill waste in this case is treated as a renewable resource that can create power or other products for green markets [3].

\section{Past Municipal Waste Management Practice in Malaysia}

In Malaysia, MSW accounts for $64 \%$ of the total solid waste. According to data from JPSPN in 2012, the MSW composition in Malaysia is food and organic (45\%), plastics (13\%), paper $(9 \%)$, diapers (12\%), garden (6\%) and others (16\%). Malaysia highly relies on the landfill as a waste disposal method although it is considered as the least preferable method because waste should undergo physical, chemical and biological treatment and segregation rather than just disposed in the landfill [19]. In the 1970s, MSW was dumped into the assigned open dumpsite by local authorities, resulting in most of the landfills in Malaysia being open dumpsites with overloaded capacity [20]. The research shows that there is about $95 \%$ of the waste ends up being dumped in the landfill, with the remaining having an intermediate treatment, feeding to the incinerators, being recycled or reprocessed, or dumped illegally [19]. Since suitable and cost-effective waste treatment remains absent, most of the overloaded sites have extended their operation time and thus pose severe environmental issues. Besides, some of the rural areas are still not equipped with proper waste collection services, the citizens can only dispose the waste through burial or open burning which contributes to illegal dumping. With the increasing population and waste generation, the existing landfill sites are facing the issue of bearing a large amount of waste but constructing a new landfill faces more difficulties because of land scarcity, high land prices and demand [21]. After the introduction of the ABC plan, the 
government set the four target levels of the landfill in order to boost the efficiency of the landfill as well as minimize the environmental impact. Table 2 presents the four target levels of the landfill, and their required facilities are provided for each level. Fortunately, the open dumpsites and unsanitary landfills are step by step being phased out and upgraded respectively as the consequences of Act 672. However, the problem regarding the increasing amount of waste remains unsolved, and the poor knowledge and participation of the public in source separation and recycling programme worsen the situation [19]. Hence, WtE technologies are urgently needed to transform the management practice into a new scenario. WtE technologies can lower the amount of waste disposed in the landfill and thus expand the landfill lifespan, reduce the emission of GHG and generate electricity simultaneously by using waste as a RE source [1]. MSW that comprises a high fraction of organic waste can be a promising biogas source in the future [3].

Table 2. Different levels of sanitary landfills.

\begin{tabular}{clll}
\hline Level & \multicolumn{1}{c}{ Description } & \multicolumn{1}{c}{ Available Facilities } & Reference \\
\hline 0 & Open dumpsite & - & {$[19,22]$} \\
I & $\begin{array}{l}\text { Controlled tipping } \\
\text { Sanitary landfill with bund } \\
\text { and daily cover }\end{array}$ & $\begin{array}{l}\text { Fencing and perimeter drains } \\
\text { Class I facilities with gas removal system, separate } \\
\text { unloading and working area, daily cover and } \\
\text { enclosing bund. Elimination of informal scavenging } \\
\text { and provision of environmental protection facilities. }\end{array}$ & \\
& Class II facilities with leachate recirculation system & \\
III & $\begin{array}{l}\text { Sanitary landfill with } \\
\text { leachate circulation } \\
\text { IV }\end{array}$ & $\begin{array}{l}\text { Sanitary landfill with } \\
\text { leachate treatment }\end{array}$ & Class III facilities with leachate treatment system \\
\end{tabular}

\section{Waste-to-energy Technology in Malaysia}

\subsection{Landfill gas recovery system}

Figure 2 demonstrates the schematic flow chart of the landfill gas (LFG) recovery process. The LFG is the product of aerobic and anaerobic decomposition of organic matter present in the MSW. The generation of LFG occurs in five stages as illustrated in Figure 3, which are hydrolysis/aerobic degradation, hydrolysis and fermentation, acidogenesis/acetogenesis, methanogenesis and oxidation. In summary, the complex organic matter is hydrolysed by hydrolytic microorganisms into soluble compounds and produces primary by-products such as $\mathrm{CO}_{2}$, water $\left(\mathrm{H}_{2} \mathrm{O}\right)$ and heat. Then, these soluble organic compounds are converted into organic acids, alcohols, $\mathrm{CO}_{2}$, hydrogen $\left(\mathrm{H}_{2}\right)$ and ammonia $\left(\mathrm{NH}_{3}\right)$ by facultative bacteria. Next, the conversion of organic acids into acetic, lactic, and formic acids, alcohols, $\mathrm{H}_{2}$ and $\mathrm{CO}_{2}$ takes place with the help of aerobic bacteria. In stage 4, the methanogenic bacteria consume the $\mathrm{CO}_{2}$ and acetate converted from the products in stage 3 and produce a large amount of LFG made up the majority by methane $\left(\mathrm{CH}_{4}\right)$ and $\mathrm{CO}_{2}$ and minority by hydrogen sulphide $\left(\mathrm{H}_{2} \mathrm{~S}\right)$, nitrous oxide $\left(\mathrm{N}_{2} \mathrm{O}\right)$ and carbon monoxide $(\mathrm{CO})$. Finally, $\mathrm{CH}_{4}$ is converted into $\mathrm{CO}_{2}$ and $\mathrm{H}_{2} \mathrm{O}$ through oxidation $[8,15,23]$. The composition of LFG mainly consists of $55 \%-65 \%$ of $\mathrm{CH}_{4}, 35 \%-45 \%$ of $\mathrm{CO}_{2}, 0 \%-3 \%$ of nitrogen $\left(\mathrm{N}_{2}\right), 0 \%-2 \%$ of oxygen $\left(\mathrm{O}_{2}\right), 0 \%-1 \%$ of $\mathrm{H}_{2} \mathrm{~S}, \mathrm{H}_{2}$, and $\mathrm{NH}_{3}$ [1]. Thus, energy recovery can be achieved through LFG combustion to generate electricity. $\mathrm{CH}_{4}$ 
can act as a substitution for fossil fuel because it is a clean source and is more cost-effective than ethanol [24].

In Malaysia, the sanitary landfills that are equipped with LFG recovery system are Worldwide Landfill Park (WLP), Bukit Tagar Sanitary Landfill (BTSL), Jeram Sanitary Landfill, Seelong Sanitary Landfill and Magenko IYO Alam Sekitar Bercham Landfill. WLP in Puchong is a rehabilitated area after the closure of the Air Hitam Sanitary Landfill in 2006. It is the first grid connector RE project in Malaysia and is able to generate $2 \mathrm{MW}$ of electricity monthly from the accumulated LFG produced by 6.2 million tonnes of MSW $[1,3]$. The generated electricity is sold to Tenaga Nasional Berhad (TNB) at the price of RM $0.4 \mathrm{kWh}$ and it is enough for the usage of 2000 houses. In the combination with Jeram Sanitary Landfill, they can provide combined generated electricity of $6 \mathrm{MW}$ for 6000 houses. BTSL in Hulu Selangor is one of the largest WtE projects which supply renewable energy from a $10.5 \mathrm{MW}$ gas engine to the national grid of TNB under the FiT scheme. The $\mathrm{CH}_{4}$ gas is captured from the first and second waste cells, which are able to produce the LFG at the rate of $3600 \mathrm{~m}^{\wedge} 3 / \mathrm{hr}$ and converted to electricity while the remaining $\mathrm{CH}_{4}$ gas is eliminated by gas flare. In addition, Seelong Sanitary Landfill and Magenko IYO Alam Sekitar Bercham Landfill contribute $2 \mathrm{MW}$ and 1.2 MW of electricity respectively.

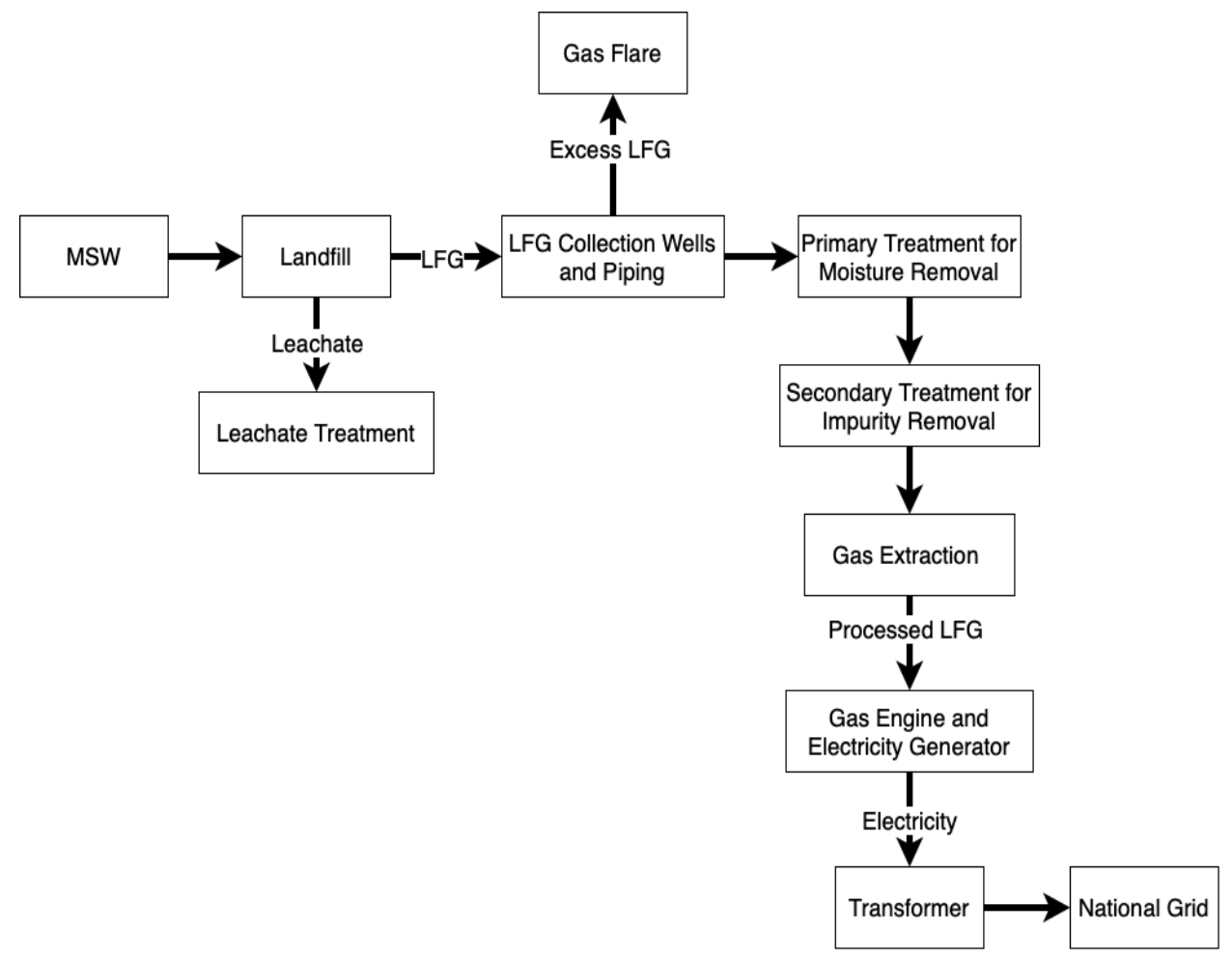

Figure 2. The schematic flow chart of landfill gas recovery process

Ideally, the LFG recovery system is the most suitable method to be implemented in Malaysia since Malaysia depends on landfill for waste disposal, but it still faces some technical limitations. Most of the landfills in Malaysia are open dumpsites or unsanitary landfill without proper equipment for LFG and leachate collection [1]. A study stated that most of the $\mathrm{CH}_{4}$ is produced early in the lifetime of the landfill which optimal amount of $\mathrm{CH}_{4}$ can be extracted [25]. Hence, most of the generated LFG of the previous landfill may escape into the atmosphere through the cracks within the waste cells [1]. The LFG production can vary due to several 
factors, including waste composition, waste age, $\mathrm{pH}$, moisture content, temperature, presence of $\mathrm{O}_{2}$, landfill type and operational practice [26]. Besides, the low participation in source separation and recycling practices causes the MSW to consist of a high amount of undegradable material, leading to a reduction of energy production in terms of economics [28].

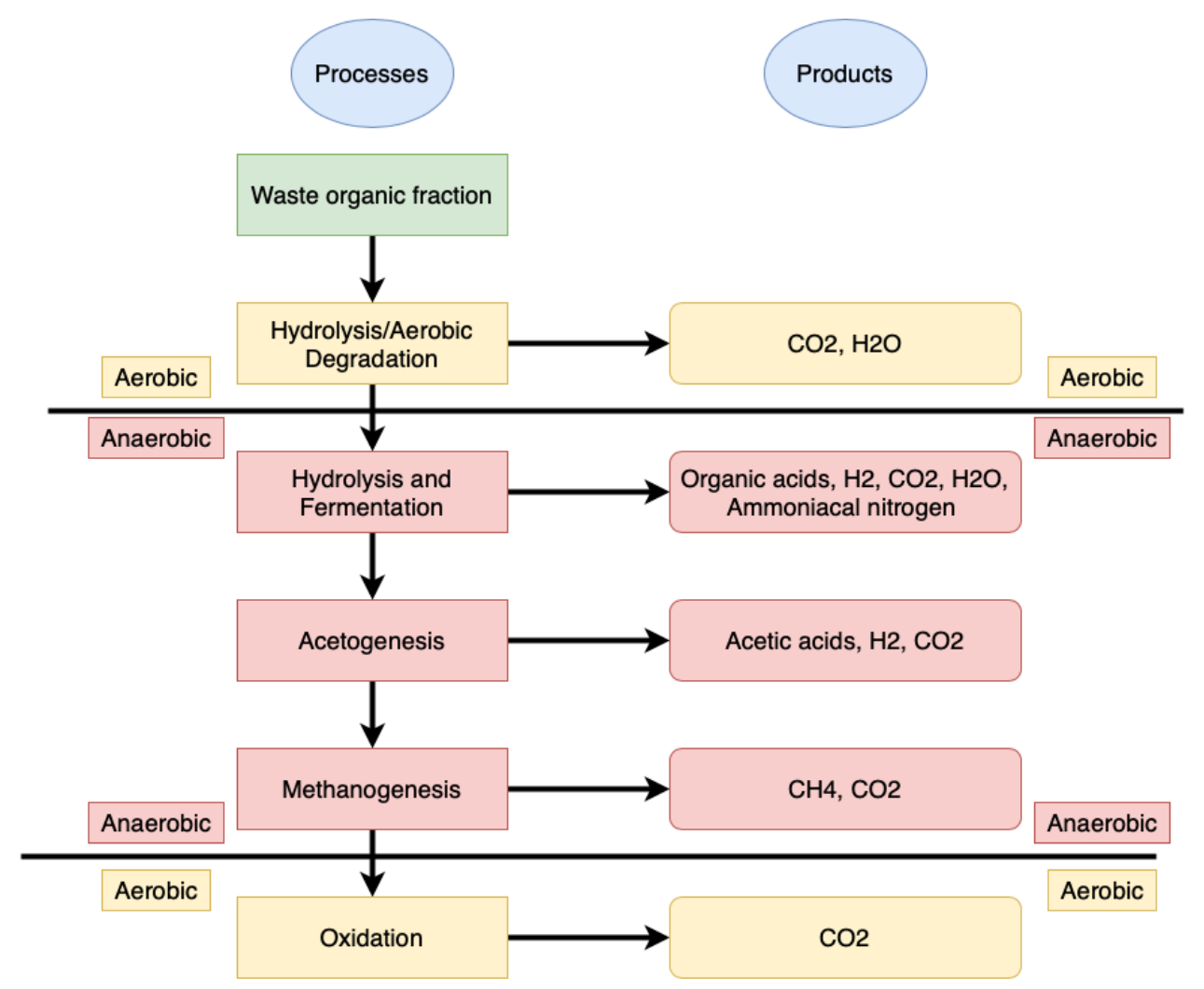

Figure 3. Major stages of waste degradation in landfill

\subsection{Incinerator}

Figure 4 displays the schematic flow chart of the MSW incineration process. Incineration is a type of thermal WtE technology that can greatly reduce the volume of MSW to about $90 \%$, protect the environment from pollution of hazardous waste and generate electricity at the same time [15]. Its mechanism is typically a combustion process in the furnace or boiler under high pressure at a temperature between $850{ }^{\circ} \mathrm{C}$ and $1100{ }^{\circ} \mathrm{C}$, and hot combusted gas consisting of $\mathrm{N}_{2}, \mathrm{CO}_{2}, \mathrm{H}_{2} \mathrm{O}$, flue gas, $\mathrm{O}_{2}$ as well as the non-combustible residue is produced. The hot flue gases act as a hot stream to generate steam from the water after entering the heat exchanger. Through the Rankine cycle in the steam turbine, electricity is generated [27]. The calorific value of MSW in Malaysia is ranging between 1540 and $2640 \mathrm{kcal} / \mathrm{kg}$ while the average [28. moisture content is $55 \%$ [16,28]. Incineration is the best to suit for MSW with low moisture content and non-biodegradable. Since MSW in Malaysia has a high fraction of organic compounds which then contribute to high moisture content, it should be pre-dried before entering the combustion chamber in order to lower the moisture content [27]. This is because the high moisture content will lead to the reduction of calorific value due to the latent heat of vaporization, and thus have a negative impact on the combustibility of MSW [15].

According to JPSPN, there are currently five incinerators being used on a small scale in the tourism spot, including Pangkor island (20 ton/day), Langkawi island (100 ton/day), 
Tioman island (15 ton/day), Cameron Highland (40 ton/day) and Labuan (50 ton/day). Unfortunately, the incinerator in Tioman island is shut down because of the high operating cost, high fuel cost resulting from the high moisture content of MSW, and there is also lack of expert technicians in maintaining the incinerators [29]. For the remaining four incinerators, the incinerator in Langkawi island manages to utilize the MSW to generate electricity while the others are used to minimize the incoming MSW volume only. The incinerator in Langkawi island is the most comprehensive plant which is able to process 100 tonnes of MSW per day to produce $1 \mathrm{MW}$ of electricity. It is also the only incinerator plant in Malaysia that segregates the solid waste into both combustible waste and wet waste before feeding into the incinerator. It can achieve an efficiency of 80-90\% [1].

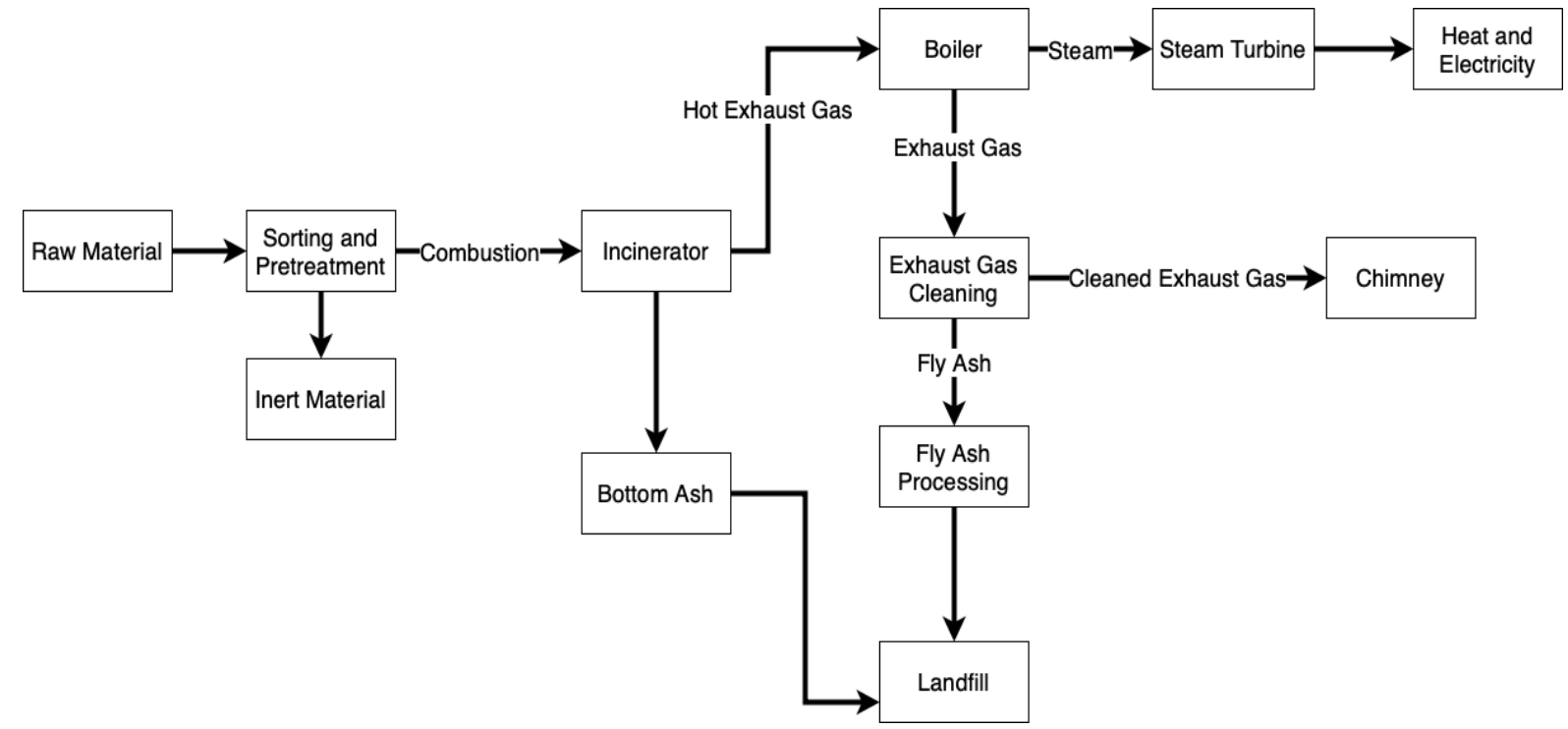

Figure 4. The schematic flow chart of MSW incineration process

\subsection{Refuse-derived fuel (RDF)}

Refuse-derived fuel (RDF) is a specialized subset of incineration in which the MSW is converted into RDF through combustion. The RDF process generally comprises four steps, which are the physical separation of incombustible material, moisture reduction, size reduction and palletizing/densification. The purpose of palletizing MSW is to homogenize the waste in order to improve the efficiency of the process [16]. The benefits of using RDF are higher thermal values, homogeneous in both physical and chemical composition, simple to transport and store, low emission rate and low excess air requirements during combustion. Besides using for electricity generation, RDF can also be a coal substitute in cement manufacturing which is an environmentally sustainable and low carbon emission approach [30].

The first and only RDF plant in Malaysia is located at Semenyih, Selangor. It has the capacity to process 700 tons of MSW per day stated by JPSPN and it generates $8 \mathrm{MW}$ electricity, in which the $3 \mathrm{MW}$ is used by the power plant itself, and the remaining $5 \mathrm{MW}$ is sold to the national grid via the FiT scheme. In addition, the plant is planning to increase the sold electricity from $5 \mathrm{MW}$ to $6 \mathrm{MW}$ and enhance the energy recovery efficiency from $77 \%$ to $83 \%$ by mixing it with biogas derived from the anaerobic digestion process [1]. This facility is beneficial as it incorporates visual, mechanical and magnetic sorting of MSW so that it only combusts the waste with high calorific value [16]. 


\section{Environmental and health impacts}

Although incineration is believed as one of the most efficient WtE technology, it may cause environmental pollution as well. The incineration process will produce bottom and fly ashes as well as flue gas that contain toxic compounds. Heavy metal is one of the examples that transfer from MSW to incineration residues as they cannot be degraded or destroyed. The presence of heavy metal not only contaminates soil and water through accumulation but also threatens human health [31]. Besides, the flue gas emitted by the incineration process consists of particulate matter, nitrogen oxides, sulphur oxides, dioxins and furans. These compounds are all the major contributors to air pollution, acid rain and smog. Also, they all have negative impacts on human health especially dioxins namely polychlorinated dibenzo-p-dioxins, polychlorinated dibenzofurans and polychlorinated biphenyls are highly carcinogenic that can cause various cancers. Therefore, the incineration plant is supposed to be implemented with air pollution control equipment such as an electrostatic precipitator in order to minimize the emission of air pollutants into the atmosphere [15].

Assamoi and Lawryshyn (2012) conducted a life cycle impact assessment to analyze the global warming potential (GWP), acidification potential (AP) and nutrient enrichment potential (NEP) for the two WtE technologies. GWP was analyzed using the model developed by the Intergovernmental Panel on Climate Change 2006 and have a time frame of 100 years. Combustion of methane and plastic is the contributor for $\mathrm{CO}_{2}$ emission in landfills and incinerators respectively. The LFG recovery system successfully controls the emission of $\mathrm{CH}_{4}$ and volatile organic compounds and a large amount of $\mathrm{CO}_{2}$ is being removed. For the incineration process, plastic only contributes to little $\mathrm{CH}_{4}$ generation due to its stability. AP measures the emission of nitrous oxide, sulphur oxide and $\mathrm{NH}_{3}$ that may cause air acidification. The result shows that incineration had higher AP compared to the LFG recovery system as it emitted higher concentrations of sulphur dioxide, nitrogen dioxide and hydrogen chloride. NEP accounts for the presence of phosphorus and nitrogen in water as well as nitrous oxide in the air that may result in eutrophication [32]. The incineration process emits higher nitrous oxide to the air added on with the leachate produced by the remaining waste disposed in the landfill. The emission from the landfill is mainly because of the generated leachate. It is important to note that the leachate generated in the landfill should be well treated as it contains various toxic organic compounds, heavy metals, as well as ammonia nitrogen compounds that may contaminate the soil and groundwater. A study also concluded that incineration has a higher carbon footprint than that of the LFG recovery system [4]. Taking electricity generation into consideration, incineration has greater performance than the LFG recovery system as it produces more electricity which then offsets the environmental impacts. However, methods to increase the efficiency of $\mathrm{WtE}$ technologies should be explored as well to minimize the environmental impact as least as possible [32].

\section{Future Challenges and Prospects}

The application of $\mathrm{WtE}$ technologies, especially incineration is unavoidable in the future in order to reduce the volume of waste being disposed in the landfill. Thus, the local authorities should promote and educate the benefits of $\mathrm{WtE}$ technologies to the public to prove the safety of the technologies and provide proper knowledge to them [16]. The government should also provide training on the treatment systems in order to solve different kinds of technical 
problems. Besides, Integrated Solid Waste Management should be implemented by integrating the covering generation, transfer, segregation, sorting, recovery, treatment, and disposal in order to have the best efficiency in resource utilization. In addition, the government should enforce the existing policies and take actual implementation by understanding the association between policy measures and the current behavioral intention of the public [18]. A strong linkage and cooperation between each solid waste management sector is required to provide adequate coverage of collection systems, efficient transportation between collection points, efficient collection methods and a proper disposal practice with source separation and recycling so that accuracy and consistent data can be generated for policy makings. To increase the awareness, interest and participation of the public, the local authorities should organize a campaign or provide education related to their behavior and the consequences of their action in hygiene and aesthetic issues through media or door-to-door approach. Schools should set solid waste management as a subject to cultivate the practices since young. It should be noted that the monetary rewards are not a long-term solution for encouraging recycling, but the public should realize the importance of recycling and do it willingly. The government should also supply recycle bins, recycling drop-off centers and recycling facilities to ease the public in the practices and maximize the recycling rate $[18,19]$.

Other than that, Malaysia can use an alternative approach rather than incineration and LFG recovery system. The $\mathrm{WtE}$ technologies such as anaerobic digestion (AD) can treat the organic portion of the waste while gasification and pyrolysis can be applied for inorganic waste [1]. The food waste treated by $\mathrm{AD}$ produces biofertilizers and biogas that can be used to generate electricity or undergo an upgrading process so that it can be used as cooking gas and vehicle fuel. Besides that, AD is a more environmentally friendly approach than the LFG recovery system for organic waste. It can be applied to a wider range of organic substrates and conducted in all geographical locations [33,14]. Pyrolysis and gasification processes can produce useful secondary fuel namely synthesis gas, heat and electricity at the same time through the reaction with organic MSW without direct combustion. Unlike incineration, both processes have cleaner emissions without any health risks to the public. Although the initial cost for gasification is 1.5 times higher than incineration, it is $30 \%$ more efficient than incineration which can offset the high capital cost [33]. The MSW has the characteristic of high moisture content, low calorific value and energy density, poor grindability and low $\mathrm{H} / \mathrm{C}$ and $\mathrm{O} / \mathrm{C}$ ratio might affect the quality of generated fuel. Therefore, the fuel produced from thermal treatment can be pretreated via torrefaction to boost raw biomass to a refined fuel with, enhanced properties like greater heating value and carbon content [13,34]. Furthermore, pretreatment for MSW before landfill through windrow composting can reduce the bulk density and the total mass of MSW transported to the landfill [35]. Construction waste reduction should refer to Singapore's practices by establishing complete guidelines on overall waste management, providing price advantage to recycled materials [23].

\section{Conclusion}

Solid waste management is a great environmental concern in Malaysia owing to the rapid urbanization and modernization. The waste disposal in Malaysia is landfill and most of the landfills are without proper engineering design. WtE technologies serve as the alternative approach in Malaysia rather than landfill that can achieve several outcomes such as reducing the waste volumes disposed in landfill, increasing the lifespan of the landfill, generating 
electricity to fulfil the energy demand, cutting down the greenhouse gas emission from the landfill and fossil-fuel based energy generation and minimizing the environmental impacts. Limitation in LFG production, high undegradable content leading to efficiency reduction, limited space for some landfills to equip with LFG recovery system which results in LFG escaping through cracks. The MSW in Malaysia has the characteristics of high moisture content, high operation cost and lack of technical skills, leading to the closure of the incinerator. Incineration technology is opposed by the public due to the emission of heavy metals, dioxin and furan that may bring negative impacts to both environment and human health. There is also a RDF plant in Malaysia that generates $8 \mathrm{MW}$ of electricity for self-usage as well as selling to the national grid. From the result of the conducted life cycle assessment, incineration is more environmentally friendly than the LFG recovery system even though it has higher GWP, AP, NEP and carbon footprint. This is attributed to the greater efficiency and electricity it produced which then can offset the environmental impacts. Several challenges are faced in solid waste management today, including public opposition against incineration, financial issue, technical limitation, lack of source separation and recycling practices, lack of public participation and responsibility, the poor connection among each stakeholder and insufficient and inaccurate data for policy makings. Hence, the government should implement a well-integrated solid waste management system, promote cooperation among stakeholders, enforce the existing policies, cultivate recycling practice among the public, and approach other WtE technologies in the future. In the author's opinion, the public should have a proper understanding and practice on reuse, reduce and recycling to minimize the waste and ease the work for source segregation so that a better efficiency of WtE technologies can be achieved.

\section{Acknowledgments}

The authors thank Curtin University Malaysia for facilitating this work. Collaboration from BNU-HKBU United International College China, Universiti Malaysia Pahang Malaysia, and Institute of Technology Cambodia are highly appreciated.

\section{Competing Interest}

The authors declare that they have no known competing financial interests or personal relationships that could have appeared to influence the work reported in this paper.

\section{References}

[1] Yong, Z.J.; Bashir, M.J.; Hassan, M.S. (2021). Biogas and biofertilizer production from organic fraction municipal solid waste for sustainable circular economy and environmental protection in Malaysia. Science of The Total Environment, 776, 145961. https://doi.org/10.1016/j.scitotenv.2021.145961.

[2] Ng, W.P.Q.; Lam, H.L.; Varbanov, P.S.; Klemeš, J.J. (2014). Waste-to-energy (WTE) network synthesis for municipal solid waste (MSW). Energy Conversion and Management, 85, 866-874. https://doi.org/10.1016/j.enconman.2014.01.004.

[3] Bong, C.P.C.; Ho, W.S.; Hashim, H.; Lim, J.S.; Ho, C.S.; Tan, W.S.P.; Lee, C.T. (2017). Review on the renewable energy and solid waste management policies towards biogas development in Malaysia. Renewable and Sustainable Energy Reviews, 70, 988-998. https://doi.org/10.1016/j.rser.2016.12.004. s

[4] Malakahmad, A.; Abualqumboz, M.S.; Kutty, S.R.M.; Abunama, T.J. (2017). Assessment of carbon footprint emissions and environmental concerns of solid waste treatment and disposal 
techniques; case study of Malaysia. Waste Management, 70, 282-292. https://doi.org/10.1016/j.wasman.2017.08.044.

[5] Lim, Y.F.; Chan, Y. J.; Abakr, Y.A.; Sethu, V.; Selvarajoo, A.; Singh, A.; Gareth, M. (2021). Review of biowastes to energy in Malaysia: Current technology, scalability and socioeconomic analysis. Cleaner Engineering and Technology, 4, 100257. https://doi.org/10.1016/j.clet.2021.100257.

[6] Devadoss, P. M.; Agamuthu, P.; Mehran, S.B.; Santha, C.; Fauziah, S.H. (2021). Implications of municipal solid waste management on greenhouse gas emissions in Malaysia and the way forward. Waste Management, 119, 135-144. https://doi.org/10.1016/j.wasman.2020.09.038.

[7] Kaur, A.; Bharti, R.; Sharma, R. (2021). Municipal solid waste as a source of energy. Materials Today: Proceedings. https://doi.org/10.1016/j.matpr.2021.04.286.

[8] Noor, Z.Z., Yusuf, R.O., Abba, A.H., Hassan, M.A.A.; Din, M.F.M. (2013). An overview for energy recovery from municipal solid wastes (MSW) in Malaysia scenario. Renewable and Sustainable Energy Reviews, 20, 378-384. https://doi.org/10.1016/j.rser.2012.11.050.

[9] Erdogan, A.A.; Yilmazoglu, M.Z. (2021). Plasma gasification of the medical waste. International Journal of Hydrogen Energy, 46, 29108-29125. https://doi.org/10.1016/j.ijhydene.2020.12.069.

[10] Montiel-Bohórquez, N.D.; Agudelo, A.F.; Pérez, J.F. (2021). Effect of origin and production rate of MSW on the exergoeconomic performance of an integrated plasma gasification combined cycle power plant. Energy Conversion and Management, 238, 114138. https://doi.org/10.1016/j.enconman.2021.114138.

[11] Malav, L.C.; Yadav, K.K.; Gupta, N.; Kumar, S.; Sharma, G.K.; Krishnan, S.; Bach, Q.V. (2020). A review on municipal solid waste as a renewable source for waste-to-energy project in India: Current practices, challenges, and future opportunities. Journal of Cleaner Production, 277, 123227. https://doi.org/10.1016/j.jclepro.2020.123227.

[12] Hasan, M.M.; Rasul, M.G.; Khan, M.M.K.; Ashwath, N.; Jahirul, M.I. (2021). Energy recovery from municipal solid waste using pyrolysis technology: A review on current status and developments. Renewable and Sustainable Energy Reviews, 145, 111073. https://doi.org/10.1016/j.rser.2021.111073.

[13] Samad, N.A.F.A.; Jamin, N.A.; Saleh, S. (2017). Torrefaction of municipal solid waste in Malaysia. Energy Procedia, 138, 313-318. https://doi.org/10.1016/j.egypro.2017.10.106.

[14] Woon, K.S.; Phuang, Z.X.; Lin, Z.; Lee, C.T. (2021). A Novel Food Waste Management Framework Combining Optical Sorting System and Anaerobic Digestion: A Case Study in Malaysia. Energy,121094. https://doi.org/10.1016/j.energy.2021.121094.

[15] Kumar, A.; Samadder, S.R. (2017). A review on technological options of waste to energy for effective management of municipal solid waste. Waste Management, 69, 407-422. https://doi.org/10.1016/j.wasman.2017.08.046

[16] Abd Kadir, S.A.S.; Yin, C.Y.; Sulaiman, M.R.; Chen, X.; El-Harbawi, M. (2013). Incineration of municipal solid waste in Malaysia: Salient issues, policies and waste-to-energy initiatives. Renewable and Sustainable Energy Reviews, 24, 181-186. https://doi.org/10.1016/j.rser.2013.03.041.

[17] Cheng, H.; Hu, Y. (2010). Municipal solid waste (MSW) as a renewable source of energy: Current and future practices in China. Bioresource technology, 101, 3816-3824. https://doi.org/10.1016/j.rser.2021.111436.

[18] Moh, Y.C.; Abd Manaf, L. (2014). Overview of household solid waste recycling policy status and challenges in Malaysia. Resources, Conservation and Recycling, 82, 50-61. https://doi.org/10.1016/j.resconrec.2013.11.004.

[19] Moh, Y.C.; Abd Manaf, L. (2017). Solid waste management transformation and future challenges of source separation and recycling practice in Malaysia. Resources, Conservation and Recycling, 116, 1-14. https://doi.org/10.1016/j.resconrec.2016.09.012.

[20] Pariatamby, A. (2014). MSW Management in Malaysia-Changes for Sustainability. In Municipal Solid Waste Management in Asia and the Pacific Islands. Environmental Science and Engineering. Pariatamby, A., Tanaka, M. (Eds.); Springer: Singapore. pp.195-232. https://doi.org/10.1007/978981-4451-73-4 11.

[21] Abd Manaf, L.; Samah, M.A.A.; Zukki, N.I.M. (2009). Municipal solid waste management in Malaysia: Practices and challenges. Waste management, 29, 2902-2906. https://doi.org/10.1016/j.wasman.2008.07.015. 
[22] Mohd Adnan, S.N.S.B.; Yusoff, S.; Chua, Y.P. (2013). Soil chemistry and pollution study of a closed landfill site at Ampar Tenang, Selangor, Malaysia. Waste Management \& Research, 31, 599-612. https://doi.org/10.1177/0734242X13482031.

[23] Johari, A.; Ahmed, S.I.; Hashim, H.; Alkali, H.; Ramli, M. (2012). Economic and environmental benefits of landfill gas from municipal solid waste in Malaysia. Renewable and Sustainable Energy Reviews, 16(5), 2907-2912. https://doi.org/10.1016/j.rser.2012.02.005.

[24] Kurniawan, T.A.; Liang, X.; Singh, D.; Othman, M.H.D.; Goh, H.H.; Gikas, P.; Shoqeir, J.A. (2022). Harnessing landfill gas (LFG) for electricity: A strategy to mitigate greenhouse gas (GHG) emissions in Jakarta (Indonesia). Journal of Environmental Management, 301, 113882. https://doi.org/10.1016/j.jenvman.2021.113882.

[25] Omar, H.; Rohani, S. (2015). Treatment of landfill waste, leachate and landfill gas: A review. Frontiers of Chemical Science and Engineering, 9, 15-32. https://doi.org/10.1007/s11705-015$1501-y$.

[26] Manheim, D.C.; Yeşiller, N.; Hanson, J.L. (2021). Gas Emissions from Municipal Solid Waste Landfills: A Comprehensive Review and Analysis of Global Data. Journal of the Indian Institute of Science, 1-33. https://doi.org/10.1007/s41745-021-00234-4.

[27] Tan, S.T.; Ho, W.S.; Hashim, H.; Lee, C.T.; Taib, M.R.; Ho, C.S. (2015). Energy, economic and environmental (3E) analysis of waste-to-energy (WTE) strategies for municipal solid waste (MSW) management in Malaysia. Energy Conversion and Management, 102, 111-120. https://doi.org/10.1016/j.enconman.2015.02.010.

[28] Kathirvale, S.; Yunus, M.N.M.; Sopian, K.; Samsuddin, A.H. (2004). Energy potential from municipal solid waste in Malaysia. Renewable energy, 29, 559-567. https://doi.org/10.1016/j.renene.2003.09.003.

[29] Sharifah, A.S.; Abidin, H.Z.; Sulaiman, M.R.; Khoo, K.H.; Ali, H. (2008). Combustion characteristics of Malaysian municipal solid waste and predictions of air flow in a rotary kiln incinerator. Journal of Material Cycles and Waste Management, 10, 116-123. http://doi.org/10.1007/s10163-008-0207-3.

[30] Karpan, B.; Raman, A.A.A.; Aroua, M.K.T. (2021). Waste-to-energy: Coal-like refuse derived fuel from hazardous waste and biomass mixture. Process Safety and Environmental Protection, 149, 655-664. https://doi.org/10.1016/j.psep.2021.03.009.

[31] Wang, P.; Hu, Y.; Cheng, H. (2019). Municipal solid waste (MSW) incineration fly ash as an important source of heavy metal pollution in China. Environmental pollution, 252, 461-475. https://doi.org/10.1016/j.envpol.2019.04.082.

[32] Assamoi, B.; Lawryshyn, Y. (2012). The environmental comparison of landfilling vs. incineration of MSW accounting for waste diversion. Waste management, 32, 1019-1030. https://doi.org/10.1016/j.wasman.2011.10.023.

[33] Yong, Z.J.; Bashir, M.J.; Ng, C.A.; Sethupathi, S.; Lim, J.W.; Show, P.L. (2019). Sustainable waste-to- energy development in malaysia: Appraisal of environmental, financial, and public issues related with energy recovery from municipal solid waste. Processes, 7, 676. https://doi.org/10.3390/pr7100676.

[34] Abdulyekeen, K.A., Umar, A.A., Patah, M.F.A.; Daud, W.M.A.W. (2021). Torrefaction of biomass: Production of enhanced solid biofuel from municipal solid waste and other types of biomass. Renewable and Sustainable Energy Reviews, 150, 111436. https://doi.org/10.1016/j.rser.2021.111436.

[35] Norbu, T.; Visvanathan, C.; Basnayake, B. (2005). Pretreatment of municipal solid waste prior to landfilling. Waste management, 25, 997-1003. https://doi.org/10.1016/j.wasman.2005.06.006.

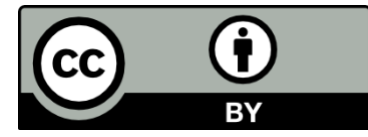

(C) 2021 by the authors. This article is an open access article distributed under the terms and conditions of the Creative Commons Attribution (CC BY) license (http://creativecommons.org/licenses/by/4.0/). 